\title{
RELAÇÕES DE GÊNERO E CONSUMO NA PUBLICIDADE DA BRAHMA NA COPA DO MUNDO DE 2010
}

\author{
Gender relations and consumption in brahma's advertising of 2010 world cup
}

\section{Relaciones de género y consumo en la publicidad de brahma en la copa del mundo}

de 2010

\author{
Camila Augusta Alves Pereira ${ }^{2}$ \\ Fausto Amaro $^{3}$ \\ Fábio Grotz ${ }^{4}$
}

\section{Resumo}

Este artigo articula três momentos. Inicialmente, fazemos um panorama dos estudos de gênero, introduzindo algumas questões para a compreensão deste tema. Em seguida, propomos algumas reflexões sobre o diálogo entre publicidade, gênero e esporte. Por último, temos a análise empírica propriamente dita, onde evidenciamos as construções de gênero e as marcações de uma suposta identidade nacional hegemônica presentes nos dois filmes publicitários da Brahma escolhidos (Lista de Pedidos e Poucas Palavras).

Palavras-chave: gênero, publicidade, identidade, Brahma.

\begin{abstract}
This article articulated three moments. First, we make an overview of gender studies, introducing some questions for the understanding of this subject. Then, we propose some reflections on the dialogue between advertising, gender and sport. Finally, we

\footnotetext{
${ }^{1}$ Este artigo é uma versão modificada do trabalho "Copa do Mundo e consumo: relações de gênero na publicidade de cerveja", apresentado no II Congresso Internacional em Comunicação e Consumo da ESPM, realizado em São Paulo nos dias 15 e 16 de outubro de 2012.

${ }^{2}$ Mestre em Comunicação Social pela Universidade do Estado do Rio de Janeiro, na linha de pesquisa Cultura de Massa, Cidade e Representação Social. Estuda idolatria, representação, identidade e publicidade em Copas do Mundo de Futebol. Membro do Grupo de Pesquisa Esporte e Cultura (FCS/UERJ), cadastrado no CNPQ. Email: camila.augusta@ yahoo.com.br

${ }^{3}$ Mestrando do Programa de Pós-Graduação em Comunicação da Uerj, na linha de pesquisa Cultura de Massa, Cidade e Representação Social, com bolsa da Capes. Membro do Grupo de Pesquisa Esporte e Cultura (FCS/UERJ), cadastrado no CNPQ. Email: faustoarp@ hotmail.com

${ }^{4}$ Mestrando do Programa de Pós-Graduação em Comunicação da Uerj, na linha de pesquisa Cultura de Massa, Cidade e Representação Social, com bolsa Faperj. Especializado em Gênero e Sexualidade pelo Instituto de Medicina Social (IMS/Uerj). Email: fabiogrotz@yahoo.com.br

Endereço: Rua São Francisco Xavier, 524, $10^{\circ}$ andar, sala 10.129, bloco F, Pavilhão João Lyra Filho Maracanã - Rio de Janeiro/RJ - CEP: 20550-900 . Telefone: (21) 2334-0757
} 
Relações de gênero e consumo na publicidade da brahma na copa do mundo de 2010

de Camila Augusta Alves Pereira, Fausto Amaro e Fábio Grotz

have the empirical analysis itself, where we noted constructions of gender and markings of a supposedly hegemonic national identity present in the two chosen commercials of Brahma (Order List and Brief).

Keywords: gender, advertising, identity, Brahma.

\section{Resumen}

Este artículo se estructura en tres momentos. Inicialmente, se realiza una visión general de los estudios de género, la introducción de algunas preguntas para la comprensión de este tema. Entonces, proponemos algunas reflexiones sobre el diálogo entre la publicidad, el sexo y el deporte. Por último, tenemos el análisis empírico en sí, donde evidenciamos las construcciones de género y las marcas de uma supuesta identidad nacional hegemónica en los dos anuncios seleccionados de Brahma (Lista de Deseos y Pocas Palabras).

Palabras-clave: gênero, publicidad, identidad, Brahma.

\section{INTRODUÇÃO}

A mídia é um dos dispositivos mais poderosos de veiculação de ideias e discursos, que interpelam os sujeitos com textos verbais e não verbais. Os discursos midiáticos permitem que os indivíduos produzam formas simbólicas acerca da experiência sensível da realidade que os cercam. A identidade na sociedade contemporânea está em constante mediação pelo discurso dos meios de comunicação, que fornecem "moldes" fluidos e mutáveis de formas de ser sociais e pessoais. A publicidade funciona como um elo entre a esfera da produção e a esfera do consumo, atribuindo significados para o que consumimos (ROCHA 2000, BELELI 2007).

Entendemos a publicidade e o futebol como veiculadores de representações e construtores de identidade, que podem nos levar à compreensão do contexto social, material e cultural em que vivemos. Sabemos que as mais fortes essencializações do brasileiro são encontradas no samba, no carnaval, no verão, na religião e no futebol, como afirma Roberto DaMatta (1982) - constituidoras de nosso ethos nacional e de nossa "imagem" no exterior. O universo que envolve o futebol produz discursos sociais variados, através de eventos como a Copa do Mundo, empreendimento integrado à 
Relações de gênero e consumo na publicidade da brahma na copa do mundo de 2010

de Camila Augusta Alves Pereira, Fausto Amaro e Fábio Grotz

lógica comercial e capitalista. O interesse nacional pelo futebol sempre foi incorporado pela mídia, criando um circuito de comunicação e consumo, que assume papel simbólico como definidor de práticas culturais e identitárias.

Dessa forma, este artigo se propõe a pesquisar as relações de gênero presentes na publicidade da marca de cerveja Brahma, veiculada durante a Copa do Mundo de 2010. Por meio dos recursos audiovisuais e cenográficos dos filmes publicitários Lista de Pedidos e Poucas Palavras esperamos entender como a marca utilizou estereótipos, associando comportamentos, valores e atitudes próprias do gênero masculino, para construir um universo de estímulo ao consumo da cerveja. Nessa Copa, a empresa investiu na publicidade com a temática Brahmeiros Guerreiros para apresentar o povo brasileiro e os jogadores da seleção nacional como guerreiros. Na campanha, a agência de publicidade África, responsável pelos filmes da marca, fez uso de personagens representativos do povo brasileiro, e junto com a Brahma adotou a narrativa sobre o comportamento heroico do povo brasileiro e do jogador de futebol, buscando criar um contexto de identificação da marca com o consumidor e com os atletas em campo.

Destacamos que o estudo da publicidade da Brahma neste trabalho partirá do aporte metodológico baseado na Análise do Discurso Crítica, proposta por Fairclough (Language and power 1989), uma vez que o conteúdo da publicidade investigada se apresenta como forma de prática social e modo de ação sobre a sociedade. A partir dessa abordagem crítica, esperamos entender a questão do gênero na publicidade da Brahma e como esta utiliza a linguagem como prática social que naturaliza relações hegemônicas e ideologias dominantes no discurso, visando incentivar o consumo.

Este artigo se articula em três momentos distintos, porém inter-relacionados. Inicialmente, faremos um panorama dos estudos de gênero, introduzindo algumas questões e problemáticas necessárias para a compreensão deste tema. Em seguida, restringindo mais a teoria, proporemos algumas reflexões sobre o diálogo entre publicidade, gênero e esporte. Por último, temos a análise empírica propriamente dita, ainda que mencionemos os filmes analisados ao longo de todo trabalho. Nesta última etapa, evidenciaremos as construções de gênero e as marcações de uma suposta identidade nacional hegemônica presentes nos dois filmes publicitários da Brahma escolhidos. 
Relações de gênero e consumo na publicidade da brahma na copa do mundo de 2010

de Camila Augusta Alves Pereira, Fausto Amaro e Fábio Grotz

\section{ENTENDENDO O CONCEITO DE GÊNERO}

O conceito de gênero no século XX. As desigualdades entre homens e mulheres passaram a ser, além de conteúdo de contestação social, objeto de reflexão teórica. Que princípios de organização social seriam responsáveis pelas assimetrias? Que noções simbólicas e discursos dariam sentido a supostos atributos e qualidades cognitivas e físicas?

O esforço acadêmico interdisciplinar - reunindo áreas como Antropologia, Sociologia, Demografia, Filosofia, História etc - foi mostrando que o processo de diferenciação entre os dois sexos reflete uma longa e complexa rede de gramáticas simbólicas articuladas historicamente. A base fundamental para se entender a dinâmica de assimetrias reside na apropriação cultural das diferenças biológicas. A anatomia dos corpos, ao longo dos séculos, foi sendo significada de modo que os destinos de homens e mulheres fossem entendidos como "naturalmente" distintos. Masculino e feminino tornaram-se domínios opostos.

Rubin (2003) argumenta que o sistema sexo/gênero é uma realidade em todas as sociedades: levando em conta especificidades culturais, tal dinâmica estabelece arranjos e mecanismos que convertem a sexualidade biológica em crenças e ideais normativas sobre os papéis sociais a serem desempenhados por homens e mulheres. A historiadora norte-americana Joan Scott (1988) também teve um importante papel na teorização sobre o gênero. A autora propôs o gênero como uma categoria analítica para investigar as relações de poder existentes entre homens e mulheres.

É importante abordar a maneira como os códigos de regulação e organização de gênero forjaram-se no Brasil. Com o desembarque da colonização portuguesa, a ordem patriarcal enraizou-se: as noções de homem/macho e mulher/fêmea tornaram-se basilares no cotidiano. O patriarca detinha o poder absoluto na administração das terras, da justiça e de outros âmbitos da sociedade. Detinha o poder sobre a mulher. A relação entre os sexos estabeleceu-se segundo o princípio da contraposição: o homem era o lado forte e nobre; a mulher, o lado fraco, débil e belo. Investido de poder, o homem assumiu a condição de superioridade que deveria abarcar o fluxo geral do cotidiano. A vitalidade, a agressividade e a virilidade eram vistas como virtudes. 
Relações de gênero e consumo na publicidade da brahma na copa do mundo de 2010

de Camila Augusta Alves Pereira, Fausto Amaro e Fábio Grotz

Gesticular, andar, escolher profissões, optar por esportes e tantas outras atividades foram sendo revestidas de significados generificados. Nessa dinâmica, consolidou-se um padrão duplo de moralidade: aos homens era permitida a liberdade do gozo físico do amor; o sexo era um evento de auto-afirmação; às mulheres, restaria o papel de extensão de seus maridos; o sexo, para elas, era um exercício de procriação, não de prazer. Tal moralidade repercutiu na ocupação dos espaços: elas ficariam em casa, cuidando da prole e do ambiente doméstico; eles eram seres do mundo público, ligados a atividades políticas, econômicas e gerenciais.

Ao longo do século XIX, no Ocidente, a ciência médica investiu na produção de saber sobre os corpos, que a partir da Idade Média já tinha sido submetidos a um intenso e multifacetado (político, religioso, moral, cultural) processo de significação de suas funções, suas partes e eventos fisiológicos. O corpo foi investido de valores, de éticas e de regulamentações: tornou-se um reduto de definição da identidade dos indivíduos, um símbolo de ordem ou desordem (LE GOFF 2011).

A racionalidade técnico-científica repercutiu na construção social das relações de gênero. Foucault (1993) destaca como, no Ocidente, a sexualidade foi incitada e acionada por diversos saberes. Houve um investimento especialmente incisivo sobre o corpo das mulheres, entendido como frágil. Uma série de pesquisas vinculou movimento que persiste até os dias atuais - aspectos fisiológicos à existência de uma essência feminina. Hormônios, sistema neurológico e sistema reprodutivo foram - e são - investigados à procura de uma explicação elementar das mulheres. Não à toa, a ginecologia é uma especialidade consolidada; ao passo que a trajetória histórica da medicina não resultou em especialidade voltada para os homens, cujos corpos, supostamente, seriam invulneráveis face à "natural” superioridade.

Os modelos simbólicos de organização das relações de gênero e da sexualidade, no entanto, não são da ordem da interdição apenas. Há um espaço de liberdade: de acordo com Parker (1991), a ideologia do erótico é um campo no qual as transgressões às normas são permitidas. É o espaço no qual o desejo, o prazer e o corpo são positivados. As categorias de homens e mulheres não são necessárias; as hierarquias se anulam diante das fantasias e da finalidade última do prazer. Como exercício reflexivo, talvez seja válido pensar como a exploração do erótico pela mídia, sobretudo apostando 
Relações de gênero e consumo na publicidade da brahma na copa do mundo de 2010

de Camila Augusta Alves Pereira, Fausto Amaro e Fábio Grotz

no corpo da mulher, e da agressividade dos homens estejam articulados no contexto simbólico de construção da experiência sexual e de gênero no Brasil.

Os estudos das relações de gênero têm experimentado uma mudança de direção. Nos últimos anos, o que antes consistia em uma preponderância da mulher como objeto de estudo amplia-se para os homens, com os estudos sobre masculinidade. A centralidade da mulher foi sendo problematizada tendo em vista que se passou a reconhecer os reflexos que as normas de gênero tinham sobre a vida dos homens: "[...] se pararmos para pensar, os valores atribuídos à masculinidade, como força, autossuficiência, invencibilidade e agressividade trazem também uma série de desvantagens aos homens. [...] os homens jovens estão muito mais suscetíveis às diferentes formas de violência urbana" (CARRARA 2010a : 32).

O processo de aprendizagem das normas de gênero, posto em funcionamento por diversas instituições - família, Igreja, escola, Estado etc - remete, de acordo com Bourdieu (2011), para além da arbitrariedade cultural. As relações entre homens e mulheres, marcadas pela dominação masculina, seriam da ordem das percepções e cognições, enraizadas de tal forma que antecederiam à consciência. O pensamento, as emoções e as ações estariam, portanto, sob a ação de estruturas simbólicas androcêntricas. $\mathrm{O}$ inconsciente governaria as relações sexuais e de gênero conforme as representações ideológicas e hegemônicas na sociedade.

A supremacia androcêntrica se forja, para Bourdieu (2011), através de rituais de masculinização e virilização, cujos fundamentos estão ligados à apreensão da biologia como estrutura definidora de regras e expectativas sociais. Tal supremacia é, antes de tudo, simbólica e baseada em uma dissimetria que estipula o homem como sujeito e a mulher, como objeto, separada do homem por um coeficiente simbólico negativo. Nesse jogo de poder, emerge um mercado de bens simbólicos e assimilado pelas próprias mulheres, que incorporam os esquemas de percepção da visão androcêntrica.

O crescente olhar para os homens não foi a única ampliação no horizonte dos estudos de gênero. No final do século XX, emergem os estudos queer, que têm como referência principal a filósofa norte-americana Judith Butler. Para a autora, é um equívoco refletir e criticar o modelo de configuração social que opõe homens e mulheres pelas categorias do masculino e do feminino. O gênero, para Butler (1990), não é uma construção linear ou definida em termos de uma estabilidade de categorias. 
Relações de gênero e consumo na publicidade da brahma na copa do mundo de 2010

de Camila Augusta Alves Pereira, Fausto Amaro e Fábio Grotz

Adotar a concepção binária como ponto de partida implica em assumir o ponto de vista de uma relação de continuidade entre gênero e sexo biológico; uma espécie de determinismo cultural, que impõe fundamentos que, ao invés de serem questionados, tornam-se substância dos discursos contestadores. É preciso, de acordo com Butler (1990), encarar a dinâmica das relações sexuais e afetivas através das experiências em si, desgarradas de princípios e categorias fixas de análise. Gênero e sexualidade, nesse sentido, devem ser desassociados teoricamente. Desviando-se da objetividade dos conceitos de masculino e feminino, prevaleceria a dinâmica da subjetividade enquanto força organizadora das experiências sexuais e afetividas.

Seja qual for o ponto de vista, parece claro que cada sociedade dispõe de representações e discursos que orientam a organização do cotidiano, dão ordem ao mundo, facilitando a convivência e o diálogo entre os indivíduos (MOSCOVICI 2011). As forças e as instituições que processam os significados de gênero são múltiplas e variadas. Tais forças codificam uma ética sobre o uso dos corpos, sobre as práticas adequadas e desaconselhadas; conduzem mentalidades e emoções; moldam competências específicas; abastecem saberes e atividades profissionais - como a publicidade -, que estão inseridas em sociedades cujas relações de gênero estão postas na ordem do dia.

\section{NOTAS SOBRE PUBLICIDADE, GÊNERO E ESPORTE}

Em uma explicação simplista, a publicidade veicula representações por meio de linguagens. Representações de gênero, raça, religião. Linguagens sonoras, visuais, textuais. Ela nos auxilia, juntamente com outras mídias e, claro, com nossa própria vivência cotidiana a compreender o mundo em que vivemos, ainda que, na maioria das vezes, por meio de estereótipos. Nesse sentido, refletimos, neste artigo, sobre essas construções estereotipadas em dois comerciais da campanha Guerreiros Brahmeiros. Que imagem do brasileiro a marca deseja transmitir, como se dá a construção de gênero, qual o lugar que o futebol ocupa nessa relação entre identidade e gênero.

Knoll destaca "o papel da comunicação midiática e, especialmente, do discurso publicitário na produção e manutenção de identidades de gênero" (2007: 1). Gastaldo, com um forte viés crítico, confere à mídia o papel de definidora da realidade na 
Relações de gênero e consumo na publicidade da brahma na copa do mundo de 2010

de Camila Augusta Alves Pereira, Fausto Amaro e Fábio Grotz

sociedade contemporânea: "Uma das formas de representação utilizadas pela mídia (e em particular pela publicidade) é o recurso a estereótipos." (2002: 69, grifos do autor). O problema desse tipo de construção simplificadora é o reforço a certos preconceitos, ideologias e visões deturpadas de determinados grupos sociais. O tempo ínfimo (normalmente menos de um minuto) e a necessidade de uma mensagem curta e eficaz colaboram para a banalização das representações. Por exemplo, nos anúncios publicitários com temática esportiva, os torcedores estão quase sempre "fantasiados" de Brasil, com direito a camisa, bandana, pinturas no rosto, para não deixar dúvida sobre o seu propósito principal. Nesse contexto, o ato de consumir "Brasil" poderia ser visto como um afirmador de nosso "eu”, frente às diferenças do outro (representado pelas seleções adversárias).

Não podemos nos esquecer que a publicidade não é a única veiculadora de significações, estando sempre em diálogo e conflito com outros media, bem como com a sociedade, pela hegemonia e validade de seu discurso. A publicidade trata necessariamente de um mundo idealizado, tecido segundo os interesses da marca, ainda que os publicitários insistam que "a propaganda é mera descrição da realidade" (BELELI 2007: 207). Sendo assim, as agências refletem sobre o que faria um consumidor escolher dada cerveja em detrimento da outra, e deste modo, optam por apelar a uma "suposta essência" da bebida que seria fruto de nossa própria identidade enquanto brasileiros. Logo, bebendo Brahma seríamos mais brasileiros do que nosso vizinho que consome outra marca.

Em época de Copa do Mundo, “[...] o que se representa nas imagens publicitárias é o 'ser brasileiro', nossa própria identidade nacional, [...], mostrando à sociedade a representação de um ideal da "brasilidade triunfante"” (GASTALDO 2002: 82). Na Copa de 2010, a Brahma apresentou o guerreiro brahmeiro, uma mistura do típico herói nacional (genial, malandro, pouco afeito a treinos) com o herói clássico de Campbell (batalhador e esforçado). Utilizando uma expressão de Rocha (2000), podemos dizer que a Brahma vendeu sua marca como um "desejo embebido de emoção". E a eficácia da campanha é potencializada, pois “oferece a 'sensação' de que o consumidor está escolhendo livremente um modo de ser" (BELELI 2007: 194). O brahmeiro seria síntese do ser brasileiro, um modelo a ser alcançado, como se fosse possível existir apenas um modo de exercermos nossa brasilidade. 
Relações de gênero e consumo na publicidade da brahma na copa do mundo de 2010

de Camila Augusta Alves Pereira, Fausto Amaro e Fábio Grotz

Utilizar o esporte (o futebol, no caso) como mote da campanha é uma ação que se justifica ao levarmos em consideração alguns aspectos ligados ao gênero masculino. Desde a mais tenra idade e em diferentes sociedades, os duelos esportivos marcam a construção da masculinidade. Disputas corporais e verbais, próximas do jogo, estão presentes em várias tribos ("primitivas" e urbanas) como forma de afirmação de um homem sobre o outro. Associar o brasileiro à figura do guerreiro inflama, assim, o ego masculino, despertando sentimentos agonísticos necessários a competição futebolística na Copa do Mundo (confronto de seleções) e na própria vida cotidiana (batalha pelo seu espaço na sociedade).

Gabrielli, Felerico e Hoff (2008) pesquisam a representação do jogador de futebol durante e posteriormente a Copa do Mundo de 2006 (de março daquele ano até o mesmo mês do ano seguinte) em revistas semanais. As autoras concluem que "o futebol está presente na publicidade brasileira, mas não de forma intensa e recorrente durante qualquer período" (Ibid.: 129). E que o corpo dos atletas não é veiculado, salvo raras exceções, enquanto ícone de uma perfeição inalcançável, mas, sim, por outras causas como "o nome e a fama" - elas cogitam que isso possibilita uma maior aproximação com o indivíduo ordinário, consumidor dos produtos de uma marca. Os atletas são requeridos pelo meio publicitário para conceder seu prestígio a dado produto (não necessariamente ligado ao esporte). No filme Poucas Palavras, essa apropriação da "autoridade" dos ídolos futebolísticos fica evidente, em uma tentativa da marca de associar o jogador guerreiro no campo ao torcedor nas arquibancadas e bares (um brahmeiro em potencial, como somos instados a acreditar).

A Brahma também se utilizou do masculino como o gênero hegemônico, não destoando de uma regra quase implícita da publicidade e muito enraizada na cultura nacional, como vimos no tópico anterior. O homem é o guerreiro (o brahmeiro), aquele que define o que é o "ser brasileiro". Dele provém o poder tanto familiar quanto social uma visão machista, mas que ainda encontra eco na representação publicitária. O predomínio de homens nos anúncios aqui trabalhados é quase absoluto. As mulheres aparecem em planos conjunto ao lado de homens, mas em nenhum momento possuem "voz" no comercial; somente os homens se pronunciam sobre o "ser brahmeiro" e o "ser torcedor brasileiro". Essa negação ou supressão do papel da mulher no contexto norteamericano é, conforme Kimmel (1998), uma condição para afirmação da identidade 
Relações de gênero e consumo na publicidade da brahma na copa do mundo de 2010

de Camila Augusta Alves Pereira, Fausto Amaro e Fábio Grotz

masculina. Gastaldo traduz com perfeição o status da mulher nos filmes publicitários, realçando em seu texto o machismo presente nas propagandas que analisa:

Nos anúncios da Copa do Mundo, não existem muitas alusões ao relacionamento entre os gêneros: via de regra, as mulheres encontram-se segregadas do 'mundo de homens' do futebol, ou então reduzidas a meras espectadoras, sem direito a fala $e$ frequentemente em segundo plano, fora de foco ou de costas, em cenas de conjunto, representando bares, por exemplo (GASTALDO 2002).

Quando a publicidade fala do interesse feminino pelo futebol, reproduz estereótipos clássicos, como a simples atração pelo corpo dos atletas, e não pelo jogo em si; a mítica do sexo frágil, que não suporta a pressão de assistir um jogo de futebol sem a presença da figura masculina; a imagem da mulher objeto, bonita e "gostosa", mas que não se ergue enquanto protagonista da cena midiatizada e da própria vida real; a mulher como esposa, aguardando o marido em casa. Um papel, em suma, subserviente ao homem.

Exclui-se a mulher dos anúncios supostamente por ela não ser parte do públicoalvo da marca ou por não apreciarem tanto futebol ${ }^{5}$. Há aqui duas imprecisões. Mulheres bebem, sim, cerveja. Em nossos círculos de amigos, podemos perceber como o número de consumidoras de cerveja é notável e crescente. E, nos últimos anos, cada vez mais mulheres se revelam torcedoras fanáticas e, por conseguinte, clientes do produto futebol e seus derivados. Dito isto, notamos como a Brahma utiliza-se de um estereótipo antigo, mas ainda perceptível no senso comum, reforçando nosso status de "sociedade falocrática, que conserva a imposição dos homens sobre as mulheres" (ALVES 2006: 10) $)^{6}$.

Deste modo, percebemos preconceitos, tradicionalismos e elevada dose de conservadorismo na publicidade de cerveja, quando esta se associa ao futebol. Às relações plurais de gênero e de raça é dado pouco espaço.

\section{CORPUS E MÉTODO: UMA LEITURA DOS FILMES}

\footnotetext{
${ }^{5} \mathrm{Na}$ análise de dois comerciais da Cerveja Nova Schin, Costa e Souza (2011) sinalizam para uma mudança de postura na publicidade de cerveja em relação ao gênero feminino, mais participativo, menos "objeto-sexual" e com voz ativa, ainda que continue submisso aos desígnios do sexo masculino.

${ }^{6}$ Neste trabalho, Alves analisa as campanhas das marcas de cerveja Skol, Kaiser e Brahma veiculadas em canais de TV de julho de 2001 a junho de 2003, bem como realiza entrevistas para analisar a recepção desse material midiático.
} 
Relações de gênero e consumo na publicidade da brahma na copa do mundo de 2010

de Camila Augusta Alves Pereira, Fausto Amaro e Fábio Grotz

A atividade comercial voltada para o esporte começou a ser desenvolvida juntamente com o surgimento da modernidade, da prática esportiva e do fortalecimento da publicidade, que no século XIX deixava de ser uma atividade amadora. De acordo com Melo, "o esporte, fenômeno social moderno, esteve desde o início inserido na construção de um modelo de sociedade em que as ideias de consumo e espetáculo são centrais" (MELO 2008: 26).

A Brahma foi criada em 1888, no Rio de Janeiro, e hoje é uma marca reconhecida no mercado de cervejas no Brasil. Como o próprio discurso da marca afirma em sua página oficial na Internet, o futebol teria sido incorporado ao seu DNA, quando a parceria como empresa patrocinadora oficial da seleção brasileira teve início no ano de 2001.

Durante o evento em 2010, a marca adotou a temática dos Guerreiros Brahmeiros na publicidade, seguindo campanha iniciada em fevereiro de 2008, quando deixou de falar diretamente de seu produto nos anúncios para focar nos consumidores de cerveja ${ }^{7}$. A agência África, responsável pelos filmes publicitários da marca, escolheu o técnico da seleção brasileira e os jogadores Luis Fabiano, Daniel Alves e Julio Cesar como garotos-propaganda.

Buscando refletir sobre as representações presentes nos anúncios da Brahma, a partir de uma análise sobre construções estereotipadas de gênero e identidade inseridas no universo do futebol, adotamos como corpus de estudo, os filmes Lista de Pedidos e Poucas Palavras. O filme Lista de Pedidos foi o segundo comercial na campanha da Brahma para a Copa do Mundo de 2010. Veiculado em novembro de 2009, entendemos que este é o filme que mais se encaixa na temática dos Guerreiros Brahmeiros, tanto pela linguagem visual quanto o apelo discursivo no transcorrer das cenas. Personagens comuns, trabalhadores homens, narram seus pedidos, convocando e clamando jogadores a lutarem em campo e trazerem o título de hexacampeão para o Brasil.

Inserido no contexto que mistura o futebol com a guerra medieval, o filme utiliza figuras de linguagem, principalmente recursos visuais de efeito - signos gráficos e icônicos, para expressar os desejos dos torcedores e a figura do brasileiro guerreiro. A

\footnotetext{
7 Informações extraídas da página oficial da Brahma: <http://www.ambev.com.br/ptbr/imprensa/releases/2011/04/11/brahma-anuncia-patrocinio-da-copa-america-argentina\%E2\%84\%A22011\#>. Acesso em: 15 mar. 2012.
} 
Relações de gênero e consumo na publicidade da brahma na copa do mundo de 2010

de Camila Augusta Alves Pereira, Fausto Amaro e Fábio Grotz

agência África alinhou a identidade do trabalhador brasileiro com o jogador guerreiro, num clichê publicitário focado na batalha medieval.

A primeira cena do filme Poucas Palavras reforça a representação da parceria entre a Brahma e a seleção brasileira. Neste filme, o personagem principal, o guerreiro da marca, é o técnico Dunga. O filme apresenta o estereótipo do guerreiro brasileiro, destacando temas como a raça, a alegria e o esforço. Quando a raça dos jogadores brasileiros é reforçada no filme, observamos várias cenas de treinamento físico e esforço, numa afirmação da "fibra masculina" na preparação para a Copa do Mundo. O filme mostra que o brasileiro tem a confiança na vitória, e mesmo frente às dificuldades é capaz de superar e enfrentar obstáculos quando a alegria encontra a raça.

Em ambos os filmes, o gênero masculino está em destaque, já que o produto anunciado e a temática sobre os guerreiros, inseridos no universo do futebol acabam por restringir o público-alvo consumidor.

Após a breve descrição dos filmes e com a reflexão aqui proposta, entendemos que uma metodologia fundamentada na Análise Crítica do Discurso (ACD) é adequada ao presente trabalho, pois esta apresenta escopo de aplicação às diversas práticas da vida social. E o discurso da publicidade pode ser compreendido como modo de ação sobre a sociedade. Logo, a partir da ACD buscamos investigar quais crenças e instituições sociais podem funcionar como estrutura de dominação por meio de representações de gênero nos filmes da Brahma.

Seguindo o modelo tridimensional de Fairclough (1989), dividimos a publicidade em três etapas de análise (texto, prática discursiva e prática social) a fim de desmistificar a dominação do estereótipo masculino apresentada no discurso da marca. Primeiramente, cabe esclarecer que entendemos como análise da prática discursiva os processos de produção, distribuição e consumo do texto da publicidade aqui estudada, relacionados a ambientes econômicos, políticos e institucionais.

Nos filmes analisados, identificamos que os processos de produção do discurso da Brahma revelam a estratégia adotada pela agência em reforçar uma atitude guerreira do brasileiro, por meio da disposição à luta e da preparação dos atletas para a Copa do Mundo. Para tal, a marca tratou de valorizar aspectos sociais e culturais já institucionalizados de que o brasileiro é aquele que está pronto para a batalha, "que não desiste nunca". As práticas discursivas são sinalizadas com representações 
Relações de gênero e consumo na publicidade da brahma na copa do mundo de 2010

de Camila Augusta Alves Pereira, Fausto Amaro e Fábio Grotz

extremamente masculinas (ou machistas), reforçadas por elementos e expressão de força, esforço e autoafirmação nas cenas dos filmes.

Sobre a distribuição do discurso adotado, temos a dizer que a veiculação dos filmes foi nacional, porém, não podemos apontar como foi de fato o consumo do texto, já que o foco deste trabalho não comporta um estudo de recepção.

Já a análise do texto compreende o vocabulário, a coesão e a estrutura social, abrangendo neologismos, relações entre palavras e sentidos, combinação de frases, mecanismos de referência e ordem de elementos combinados. O que mais fica claro nos filmes são as associações propostas pela Brahma de que o futebol é uma batalha, e de que o brasileiro é um guerreiro. Observamos ainda que a convocação dos brasileiros a irem à luta, exclui a figura feminina da guerra e nos remete a mecanismos de referência de que durante as grandes batalhas a mulher sempre esteve em casa, pronta e a espera do retorno do homem, simbolicamente revestido de poder. Nesse sentindo, notamos que a campanha da Brahma foi direcionada para o gênero masculino, o que é reforçado quando observamos elementos ordenados e combinados como: a preparação, o esforço e $\mathrm{o}$ treino seguido da batalha. $\mathrm{O}$ triunfo final seria celebrado com a alegria do brasileiro e um copo de Brahma.

Dois aspectos presentes nos filmes da Brahma investigados são importantes para uma análise mais detida. Um é a associação entre o consumo de cerveja, a masculinidade e o ethos brasileiro. Gastaldo (2005), em pesquisa etnográfica conduzida em bares do Rio Grande do Sul, conclui que a perda de lucidez causada pela bebida alcóolica não é associada a valores de masculinidade, pelo contrário. Nesse sentido, é paradoxal a associação proposta pela Brahma entre beber cerveja como expressão de sua masculinidade. Outro ponto é a diminuição do feminino na lógica do torcer e do consumo de cerveja. Ao destacar aspectos guerreiros, ligados intrinsicamente ao homem $^{8}$, são retirados os aspectos de feminilidade, que também moldam o ser masculino, ao mesmo tempo em que se reforça o aspecto viril, que supostamente marca esse gênero. Ou seja, na construção do brasileiro pela Brahma, estão presentes aspectos inegavelmente machistas, uma vez que se renega a contribuição de qualidades femininas para a "nossa formação".

\footnotetext{
${ }^{8}$ Para uma breve análise da publicidade sobre o masculino na última década (1995-2005), bem como uma categorização dos estereótipos ligados a esse gênero, ver Garboggini (2005). Neste artigo, elas sublinham ainda o caráter "machão" do homem na publicidade de cerveja da segunda metade dos anos 1990.
} 
Relações de gênero e consumo na publicidade da brahma na copa do mundo de 2010

de Camila Augusta Alves Pereira, Fausto Amaro e Fábio Grotz

Do estudo da prática social participam aspectos ideológicos e hegemônicos, nos quais podemos analisar metáforas, estilos, e ainda orientação de práticas econômicas, políticas, ideológicas e culturais dos filmes. (RESENDE \& RAMALHO 2004: 186189). Tudo que observamos até aqui, mais os recursos utilizados nos filmes, como a metáfora e a prática cultural de que é o homem quem vai para a batalha, que pede e cobra retorno, certificam a condição superior da figura masculina na sociedade. A estratégia e a temática escolhidas para a campanha da Brahma valorizam os rituais de masculinização que vimos em Bourdieu (2011). Dessa forma, ainda que "a derrota na guerra derrube uma lágrima", a virilidade e a força do guerreiro brasileiro prevalecem e são suficientes para continuar a "lutar na vida".

As mesmas cenas que remetem à violência das batalhas épicas nos filmes, construídas a partir de um clima denso e pesado, nem de longe lembram o futebol dos jogadores brasileiros. Relacionar a guerra ao esporte, ainda que para valorizar a figura masculina do guerreiro inserida numa esfera de poder, pode acarretar uma conotação negativa ao discurso. O que podemos pensar aqui é que a publicidade da Brahma encontrou no imaginário da guerra uma forma de chamar a atenção do consumidor para seu produto e se fazer diferente das marcas concorrentes.

Com a análise acima apresentada, destacamos o uso do discurso publicitário como prática social, modo de ação historicamente situado na relação do indivíduo com a sociedade, o futebol, a bebida e a guerra. Os signos de expressão que constituem o jogador de futebol e o indivíduo brasileiro como guerreiros são manipulados no discurso da campanha como um recurso clichê "machista" para que a mensagem da marca alcance o receptor sem perder o sentindo desejado. Assim, o consumidor poderia ser induzido a se identificar com ideologias e representações do "ser brasileiro" veiculados pelo discurso publicitário.

\section{CONSIDERAÇÕES FINAIS}

A estratégia de venda da publicidade é incentivar o consumo através da associação de ideias dominantes, imagens e palavras reconhecidas que conquistem mais pessoas e mercado, objetivando maior lucro de determinada marca. Para isso, é preciso 
Relações de gênero e consumo na publicidade da brahma na copa do mundo de 2010

de Camila Augusta Alves Pereira, Fausto Amaro e Fábio Grotz

investimento, estudo do público e mercado consumidor, a partir de um planejamento adequado para se atingir o objetivo final.

Destacamos como a publicidade, no período da Copa, traz para o mundo real uma atividade, o futebol, tida como extra cotidiana e com fim em si mesmo. Atribui-se uma intenção a esse esporte. Ele é apropriado metaforicamente para servir de elemento aglutinador do social e definidor de um ethos nacional. Objetos como a bola e a chuteira são articulados aos símbolos oficiais pátrios em diversos anúncios, resultando, simbolicamente, em uma construção do nacional pautada pela ludicidade. No filme Poucas Palavras, essa apropriação do sentido nação para estimular o consumo de cerveja fica mais evidente.

A apropriação do esporte como mensagem publicitária também evidencia outros códigos culturais que excedem o domínio de uma unidade de nacionalidade. Por meio de uma linguagem permeada por significados de gênero, as peças publicitárias analisadas acionam a figura do homem como um corpo investido de força e agressividade. Um corpo masculino, cuja legitimidade é efeito de um longo processo histórico que se faz presente em práticas, instituições e valores que se articulam no cotidiano do país. Um corpo que não é absoluto, pré-discursivo e que tampouco opera no vácuo; é uma construção social.

A Brahma utiliza-se também de um argumento não pragmático, pois lúdico, para vender. Essa é uma característica típica, aliás, das propagandas atuais. Não mais se utilizam tanto argumentos de qualidade ou de quantidade objetivos - atributos racionais, apolíneos (CARRASCOZA apud FURTADO 2007: 13) - para promover um produto ou serviço. Opta-se por vinculá-lo a sentimentos ou sensações ou qualificá-lo por meio de metáforas. Por exemplo, quem pode asseverar, além da agência África e da própria Brahma, que o brahmeiro representa a essência do ser brasileiro?

\section{REFERÊNCIAS BIBLIOGRÁFICAS}

ALVES, L. "Representações e diálogos nas propagandas brasileiras de cerveja: uma abordagem comunicacional" in UNIrevista, v. 1, n. 3, jul. 2006.

BOURDIEU, P. A dominação masculina. Rio de Janeiro, Bertrand Brasil, 2011. 
Relações de gênero e consumo na publicidade da brahma na copa do mundo de 2010

de Camila Augusta Alves Pereira, Fausto Amaro e Fábio Grotz

BUTLER, J. Gender trouble: feminism and the subversion of identity. New York, Routledge, 1990.

BELELI, I. "Corpo e identidade na propaganda" in Revista Estudos Feministas, v. 15, n.1: 193-215, 2007.

CARRARA, S. et al. Gênero. Curso de Especialização em Gênero e Sexualidade. Rio de Janeiro, CEPESC, Brasília, DF, Secretaria Especial de Políticas para as Mulheres, v. 2, 2010.

CARRARA, S. et al. A construção do conhecimento em gênero e sexualidade: história e perspectivas. Curso de Especialização em Gênero e Sexualidade. Rio de Janeiro, CEPESC, Brasília, DF, Secretaria Especial de Políticas para as Mulheres, v. 5, 2010.

COSTA, D.; SOUZA, C. "Questões de gênero na propaganda de cerveja Schin” in XVI Intercom Sudeste - Congresso de Ciências da Comunicação na Região Sudeste, 2011. São Paulo, XVI Intecom Sudeste, 2011.

DAMATTA, R. (org.). Universo do Futebol. Rio de Janeiro, Pinakotheke, 1982.

FAIRCLOUGH, Norman. Language and Power. New York, Longman, 1989.

FOUCAULT, Michel. História da Sexualidade I: A vontade de saber. Rio de Janeiro, Graal, 1993.

FURTADO, J. "Identidade masculina e publicidade: uma discussão contemporânea" in III ENECULT - Encontro de Estudos Multidisciplinares em Cultura, 2007, Salvador. III ENECULT - Terceiro Encontro de Estudos Multidisciplinares em Cultura, 2007.

GARBOGGINI, F. O homem na publicidade da última década. Uma cultura em mutação? Educar em Revista, v. 26: 99-114, 2005.

GASTALDO, E. Pátria, Chuteiras e Propaganda: o brasileiro na publicidade da Copa do Mundo. São Paulo, Annnablume; São Leopoldo, Ed. Unisinos, 2002.

. "O Complô da Torcida: futebol e performance masculina em bares" in Horizontes Antropológicos. Porto Alegre, v. 11: 107-123, 2005.

HOFF, T.; FELERICO, S.; GABRIELLI, L. "Publicidade e futebol: representações do jogador na mídia impressa" in Diálogos Possíveis (FSBA), v. 12: 125-137, 2008.

KIMMEL, M. "A produção simultânea de masculinidades hegemônicas e subalternas" in Horizontes Antropológicos. Porto Alegre, v. 9: 103-117, 1998. 
Relações de gênero e consumo na publicidade da brahma na copa do mundo de 2010

de Camila Augusta Alves Pereira, Fausto Amaro e Fábio Grotz

KNOLL, G. "Relações de gênero na publicidade" in VIII ENIL - Encontro Nacional de Interação em Linguagem Verbal e Não-Verbal e II Simpósio Internacional de Análise Crítica do Discurso, 2007, São Paulo. VIII ENIL e II Simpósio Internacional de Análise Crítica do Discurso, 2007: 180-181.

LE GOFF, J. Uma história do corpo na Idade Média. Rio de Janeiro, Civilização Brasileira, 2011.

MELO, V. "Esporte, propaganda e publicidade no Rio de Janeiro da transição dos séculos XIX e XX” in Revista Brasileira Ciência e Esporte. Campinas: v. 29, n.3: 25-40, mai. 2008.

MOSCOVICI, S. Representações sociais: investigações em psicologia social. Petrópolis, RJ,: Vozes, 2011.

PARKER, R. Corpos, prazeres e paixões: a cultura sexual no Brasil contemporâneo. São Paulo, Editora Nova Cultura, 1991.

PEREIRA, C. A. Guerreiros não abandonam a batalha: publicidade e identidade do herói nacional no mundial de futebol de 2010. Dissertação (Mestrado em Comunicação) - Faculdade de Comunicação Social, UERJ, Rio de Janeiro, 2012.

RESENDE, V. de M.; RAMALHO, Viviane C. V. S. "Análise do Discurso Crítica, do Modelo Tridimensional à articulação entre práticas: implicações teóricometodológicas" in Revista Linguagem em (Dis)curso - LemD, Tubarão, v. 5, n.1: $185-207$, jul/dez, 2004.

ROCHA, E. Totem e consumo: um estudo antropológico de anúncios publicitários. Alceu (PUC-RJ), Rio de Janeiro, v. 1, n. 1: 18-37, 2000.

RUBIN, G. O tráfico de mulheres: notas sobre a "economia política" do sexo. Cadernos Pagu, n. 21: 1 a 64, 2003.

SCOTT, J. [1988]. "Gênero: uma categoria útil de análise histórica" in Educação e Realidad, v. 16, n.2, 1990.

Artigo submetido: 22/03/2013

Artigo aprovado: 17/09/2013 